Article

\title{
Petrographic and Chemical-Mineralogical Characterization of Mortars from the Cistern at Amaiur Castle (Navarre, Spain)
}

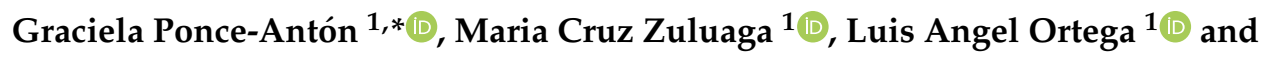 \\ Juantxo Agirre Mauleon 2 \\ 1 Department of Mineralogy and Petrology, Faculty of Science and Technology, University of the Basque \\ Country (UPV/EHU), Sarriena s/n, 48940 Leioa, Bizkaia, Spain; mcruz.zuluaga@ehu.eus (M.C.Z.); \\ luis.ortega@ehu.eus (L.A.O.) \\ 2 Aranzadi Society of Sciences, Zorroagagaina 11, 20014 Donostia-San Sebastián, Gipuzkoa, Spain; \\ zuzendaritza@aranzadi.eus \\ * Correspondence: graciela.ponce@ehu.eus; Tel.: +34-946-015-456
}

Received: 11 March 2020; Accepted: 30 March 2020; Published: 31 March 2020

\begin{abstract}
Mortars from the cistern in Amaiur Castle (Navarre, Spain) were analysed to assess the mortar manufacturing process and application techniques. To this end, optical microscopy, scanning electron microscopy (SEM), thermogravimetric analysis, X-ray fluorescence (XRF), X-ray diffraction (XRD), Raman microspectroscopy, and Fourier transform infrared spectroscopy (FTIR) were performed. The study of both structural and plaster mortars from Amaiur Castle cistern show patterns/rules in the mortar manufacture according to the specific construction requirements. A multilayer application technique was used for the construction of the cistern tank. Deliberate selection of the aggregate nature and grading contributed to mortar impermeability. Ceramic and silico-aluminous rock fragments were used as aggregates in the cistern tank to confer hydraulicity to the mortars, instead of carbonated aggregates as used in the vault. Aluminosilicated phases present in the aggregates led to the formation of amesite, which is a magnesium aluminosilicate hydrate (M-A-S-H) phase conferring hydraulicity to the mortar. Two types of additives were identified in the outer pigmented layer of plaster. Beeswax was the identified organic additive used to improve the impermeability of mortar, while hematite was the identified inorganic additive giving rise to the reddish colour of the layer.
\end{abstract}

Keywords: lime mortar; plaster; hydraulicity; reaction rim; hydrotalcite; amesite; hematite; beeswax

\section{Introduction}

Cisterns have been essential structures for water storage since the Neolithic period not only to guarantee a regular and independent water supply in regions with water shortages but also to ensure the supply during drought or siege periods, particularly in castles or fortified sites [1-4]. The need to store and supply water required improvements in the hygienic conditions of the cisterns and led to structural and technological advances in the structures [5].

The great deteriorating capacity of water constitutes one of the main causes of construction material deterioration [6]. Cistern mortars are continuously in contact with water. Therefore, to ensure the impermeability and durability of mortars in the cistern tank, specific requirements are necessary compared with other building structures, in both the mortar manufacture and application technology practices [7].

Mortar impermeability is strictly related to mortar hydraulicity [8]. In hydraulic mortars, the hardening occurs mainly by the chemical reaction with water rather than by exposure to carbon dioxide as happens in non-hydraulic mortars. The amount of reactive silicates and aluminates present 
in the mixture will determine the hydraulicity degree of mortar [9]. To obtain the waterproofing of mortars, a reactive additive, mainly pozzolanic components such as crushed bricks or calcined clays, have been added to the mixture to provide hydraulic properties to non-hydraulic mortars, improving their resistance to moisture [10-14]. Pozzolans are highly reactive materials mainly composed of aluminosilicate phases that in the presence of water react with the calcium hydroxide $\left[\mathrm{Ca}(\mathrm{OH})_{2}\right]$ and form stable aluminosilicate hydrated products that confer hydraulic properties to mortars $[8,15]$. Due to this reaction, a reaction rim can be formed surrounding the aggregates [16]. Moreover, natural organic compounds have also been added to the mixture to achieve specific behaviours in mortars [17].

The present study aims to perform petrographic and chemical-mineralogical characterisation of the structural and plaster mortars of the cistern from Amaiur Castle to assess the mortar manufacturing process and application technology used according to the specific requirements for the construction of this structure.

\section{Geological and Archaeological Setting}

Amaiur Castle (Navarre, Spain) is located geologically on Triassic limestones and dolostones, although Paleozoic and Mesozoic materials outcrop in the regional geology. The Paleozoic is characterized by Ordovician to Carboniferous metamorphic materials, consisting mainly of schist and quartzites and scarce limestones and dolomites, and by Permian carbonated and slaty breccias, limestones, and sandstones. Regionally, Triassic materials are characterised by conglomerates and sands in the Buntsandstein Facies, dolomitic limestones and dolostones in the Muschelkalk Facies, mottled clays with gypsum in the Keuper Facies, and subvolcanic basic rocks associated with the Keuper Facies [18,19].

The strategic emplacement of Amaiur Castle in the western Pyrenees allowed it to control the pass across this mountain range during the Middle Ages. Although the castle was first mentioned by written sources in the 12th century, the archaeological evidence showed an occupation period from the 13th century to the 17th century (Figure 1). Amaiur Castle defences were reinforced during the 14th century due to artillery development in that same century. Also in the 14th-15th century, a second wall reinforced the 13th-14th century medieval wall. During the 16th and 17th centuries, the castle was largely remodelled, owing to the conflicts occurring in the region at that time. In the 16th century, a circular bastion was added to the 14th-15th century medieval wall. The studied cistern was built at this time between the two medieval walls, giving rise to a rectangular-based tank cistern (Figure 2), and much of the space between the two medieval walls was filled with lime mortar. Later, in the 17th century, the fortification was transformed into a trace italienne bastion with the addition of diamond-shaped structures [20-22]. 


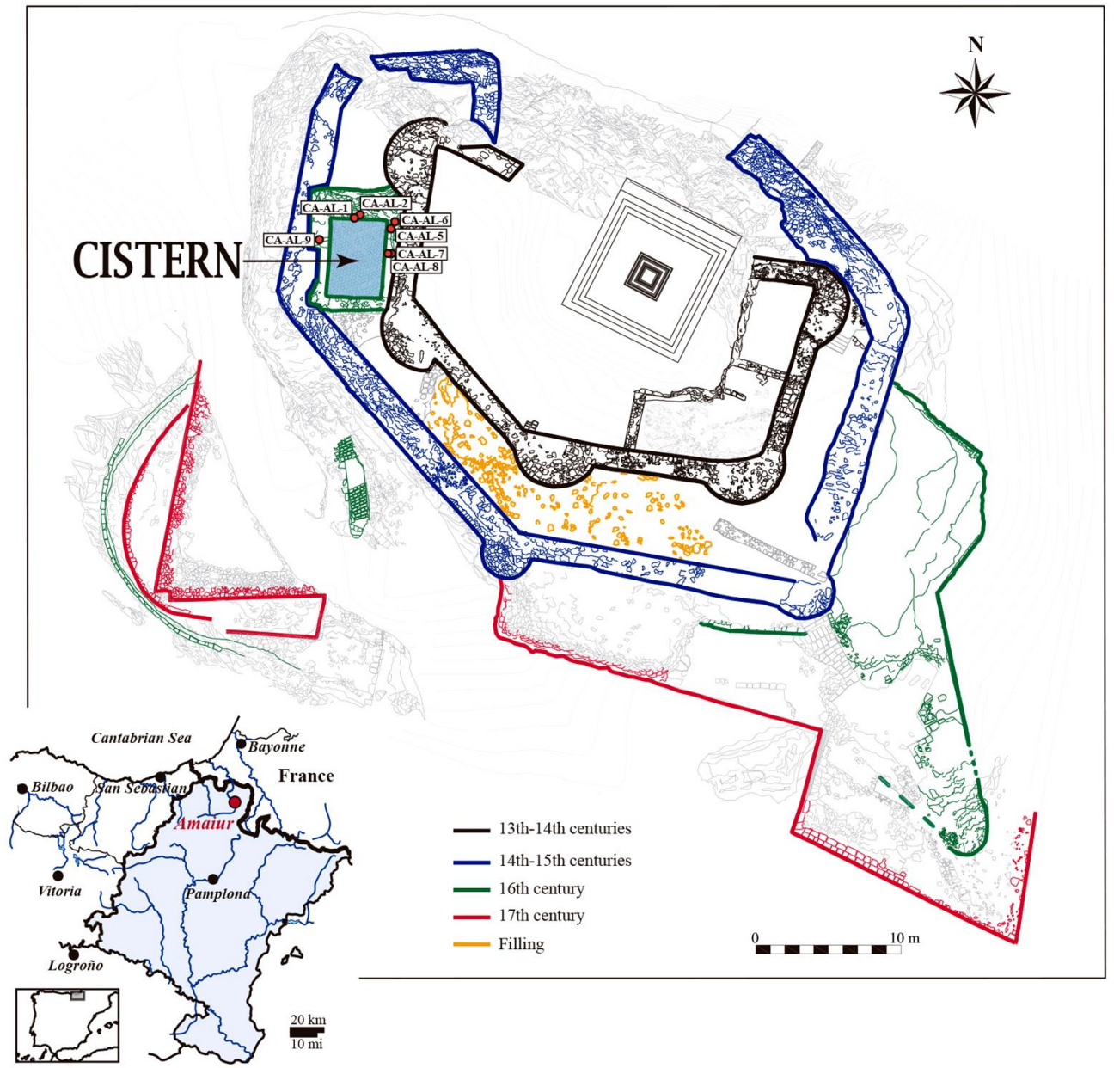

Figure 1. Geographic location of Amaiur Castle (Navarre, Spain). Studied samples are marked by red circles. Modified from Ponce-Antón et al. [23].

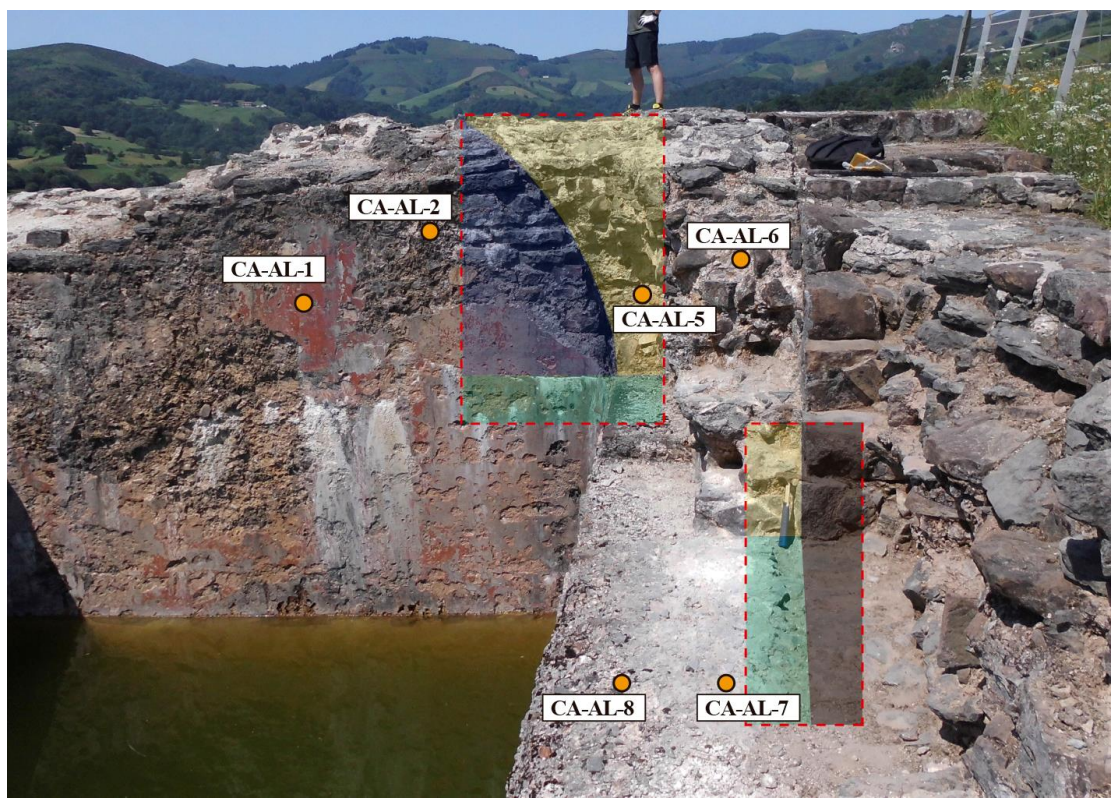

Figure 2. Location of the studied samples within the cistern. Cistern tank in green, vault lunette in blue, barrel vault in yellow, and 14th-15th centuries wall in black. 


\section{Materials and Methods}

\subsection{Materials}

Seven representative lime mortar samples were collected from the preserved remains of the cistern (Table 1, Figures 1 and 2). A total of six samples of structural mortar were collected, three from the walls of the tank (Samples CA-AL-7 and CA-AL-8 from the SE wall and Sample CA-AL-9 from the SW wall), two from the base of the barrel vault (Samples CA-AL-5 and CA-AL-6), and one from the vault lunette (CA-AL-2). Sample CA-AL-8 has been subdivided into two different samples (CA-AL-8a and CA-Al-8b) due to the granulometric differences observed on a macroscopic scale. Since both the tank walls and lunette are covered with the same plaster, an additional sample of plaster was collected from the lunette (CA-AL-1) in the area where the plastering is best preserved.

Table 1. Lime mortar samples from the different locations in Amaiur Castle cistern.

\begin{tabular}{|c|c|c|c|c|}
\hline Mortar Type & Structure & Location & & \\
\hline \multirow{5}{*}{ Structural } & \multirow[b]{2}{*}{ Barrel vault } & Lunette & \multicolumn{2}{|c|}{ CA-AL-2 } \\
\hline & & Base & \multicolumn{2}{|c|}{$\begin{array}{l}\text { CA-AL-5 } \\
\text { CA-AL-6 }\end{array}$} \\
\hline & \multirow{4}{*}{ Tank } & Inner layer & \multicolumn{2}{|c|}{ CA-AL-7 } \\
\hline & & Outer layer & CA-AL-8 & $\begin{array}{l}\text { CA-AL-8b } \\
\text { CA-AL-8a }\end{array}$ \\
\hline & & & \multicolumn{2}{|c|}{ CA-AL-9 } \\
\hline Plaster & & $\begin{array}{c}\text { Inner layer } \\
\text { Pigmented layer }\end{array}$ & \multicolumn{2}{|c|}{ CA-AL-1 } \\
\hline
\end{tabular}

\subsection{Methods}

Petrographic characteristics of mortars were studied by polarized light microscopy (PLM) (JEOL, Tokyo, Japan) on polished thin sections and in both transmitted and reflected polarized light modes using a Nikon Eclipse LV100POL polarizing microscope equipped with a DS F-11 digital camera and DS L2 camera control unit.

Scanning electron microscopy (SEM) analysis was carried out on carbon-coated polished thin sections using a JEOL JSM-7000F Schottky-type field emission scanning electron microscope (JEOL, Tokyo, Japan) equipped with an INCA EDX detector X-sight Series Si (Li) Oxford pentaFET microanalysis system.

Thermogravimetric analysis (TGA) was performed using a TA SDT 2960 TG-DSC simultaneous instrument (TA Instruments, New Castle, DE, USA). A 5 to $7 \mathrm{mg}$ of sample were heated in Pt crucibles at $2{ }^{\circ} \mathrm{C} \mathrm{min}{ }^{-1}$ from room temperature to $900{ }^{\circ} \mathrm{C}$ under a dry oxidizing atmosphere.

The semiquantitative chemical composition of major elements of the mortar binder fraction $<2 \mu \mathrm{m}$ was determined by means of X-ray fluorescence (XRF). A Wavelength Dispersive X-ray Fluorescence (WDXRF) PANalytical Axios Advanced PW4400 XRF spectrometer (with $4 \mathrm{~kW}$ Rh anode SST-mAX X-ray tubes) (Malvern PANalytical, Almelo, The Netherlands) was used to perform the analyses on a powder sample. The detection limit was of $0.01 \mathrm{wt} \%$. The loss on ignition (LOI) was calculated after heating the powder sample at $900{ }^{\circ} \mathrm{C}$.

The X-ray diffraction (XRD) analysis was performed to determine the mineralogy of powder polycrystalline samples using a Philips X'Pert diffractometer (Malvern PANalytical, Almelo, The Netherlands) equipped with a monochromatic $\mathrm{Cu}-\mathrm{ka} 1 \mathrm{X}$-radiation in a continuous scan from $5^{\circ}$ to $70^{\circ} 2 \theta$ operating at $40 \mathrm{kV}$ and $20 \mathrm{~mA}$ conditions with an acquisition rate of $0.02^{\circ}$ per second. $X^{\prime}$ Pert HighScore Plus 3.0 software by PANalytical (Malvern PANalytical, Almelo, The Netherlands) and the experimental patterns of the International Centre for Diffraction Data (ICDD) and the Inorganic Crystal Structure Database (ICSD) diffraction databases were used for the mineral phase identification. 
Micro-Raman analyses were performed using a Renishaw inVia confocal microRaman spectrometer (Renishaw inVia, Gloucestershire, UK). Spectra were acquired between 1000 and $1120 \mathrm{~cm}^{-1}$ with a $1 \mathrm{~cm}$ resolution and the data acquisition was carried out using Renishaw's WireTM 3.2 software package (Renishaw, Gloucestershire, UK). Raman spectra of pure standard compounds collected in the e-VISNICH dispersive Raman database were used to interpret the results.

Fourier transform infrared spectroscopy (FTIR) by the potassium bromide pellet technique was carried out to determine the nature of the organic compounds using a JASCO 4200 FTIR spectrometer (JASCO INTERNATIONAL CO., Hachioji, Tokyo, Japan) and acquiring spectra between 400 and $4000 \mathrm{~cm}^{-1}$.

To improve the FTIR signal of the organic components, an extraction was conducted using $200 \mu \mathrm{L}$ of dichloromethane organic solvent.

Hydraulicity Index (HI) (Equation (1)) and Cementation Index (CI) (Equation (2)) values were calculated to assess the hydraulicity of the binder according to Boynton formula [24,25]. Indices were calculated as below:

$$
\begin{gathered}
\mathrm{HI}=\frac{\mathrm{SiO}_{2}+\mathrm{Al}_{2} \mathrm{O}_{3}}{\mathrm{CaO}+\mathrm{MgO}} \\
\mathrm{CI}=\frac{2.8 \mathrm{SiO}_{2}+1.1 \mathrm{Al}_{2} \mathrm{O}_{3}+0.7 \mathrm{Fe}_{2} \mathrm{O}_{3}}{\mathrm{CaO}+1.4 \mathrm{MgO}} .
\end{gathered}
$$

\section{Results}

\subsection{Petrographic and Chemical-Mineralogical Characterization}

Macroscopically, a difference in the nature of aggregates was observed between the plaster (Figure 3a), mortars from the tank (Figure 3b-d), and the mortars from the vault (Figure 3e,f). Sample CA-AL-2 from the lunette of the vault and Samples CA-AL-5 and CA-AL-6 from the base of the barrel vault (structural mortars) show carbonated aggregates, whereas Samples CA-AL-7, CA-AL-8 and CA-AL-9 (structural mortars), and Sample CA-AL-1 (plaster) show siliceous aggregates. Mortars from the tank also show increasing aggregate grading, from structural mortars (inner part; Samples CA-AL-7, CA-AL-8, and CA-AL-9) to the plaster (outer part; Sample CA-AL-1) (Figure 3).

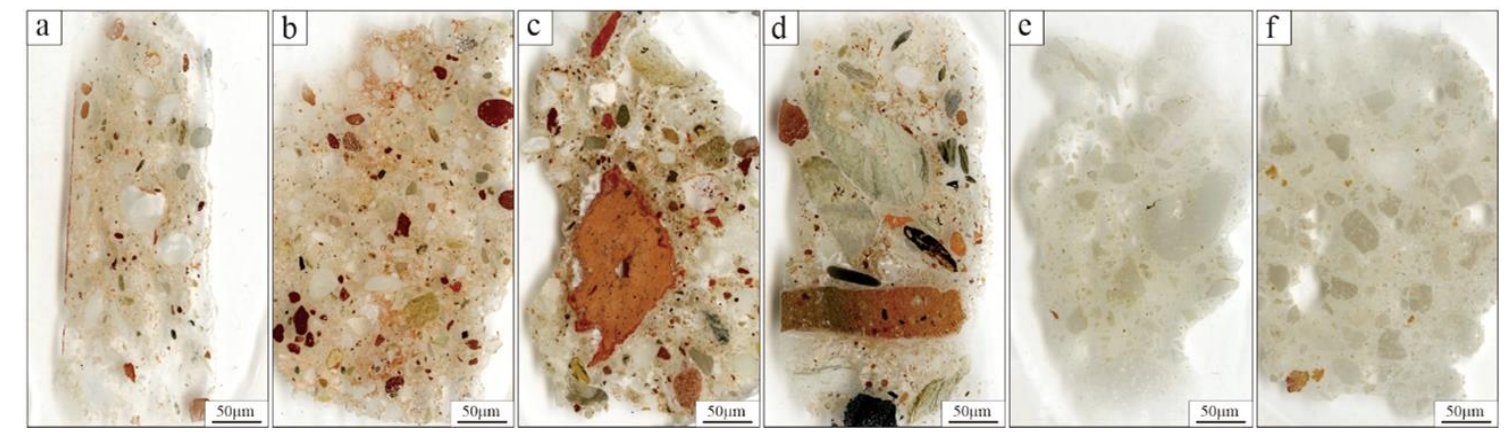

Figure 3. Macroscopic texture of the lime mortars from the Amaiur Castle cistern. (a) CA-AL-2, plaster sample. (b) CA-AL-8a, (c) CA-AL-8b, and (d) CA-AL-7, samples from the tank mortars. (e) CA-AL-2 and (f) CA-AL-5, mortars from the vault. Mortars from the tank show an increase in aggregate grading from the inner part (d) to the outer part (a).

Microscopically, all samples show a heterogeneous binder matrix-supported texture with aggregates embedded in a micritic calcite matrix. Petrographic observations of mortar identified the carbonated aggregates of samples from the vault as poorly sorted fine-grained dolostone fragments with angular to subangular shape (Figure 4a). The grain sizes of aggregates from the vault base (Samples CA-AL-5 and CA-AL-6) range from $0.2 \mathrm{~mm}$ up to $3 \mathrm{~mm}$, whereas aggregates from the lunette 
(CA-AL-2) reach $8 \mathrm{~mm}$ in size. Dolostone aggregates show a pronounced reaction zone (Figure 4a). Scarce ceramic fragments can also be observed dispersed in the binder matrix.
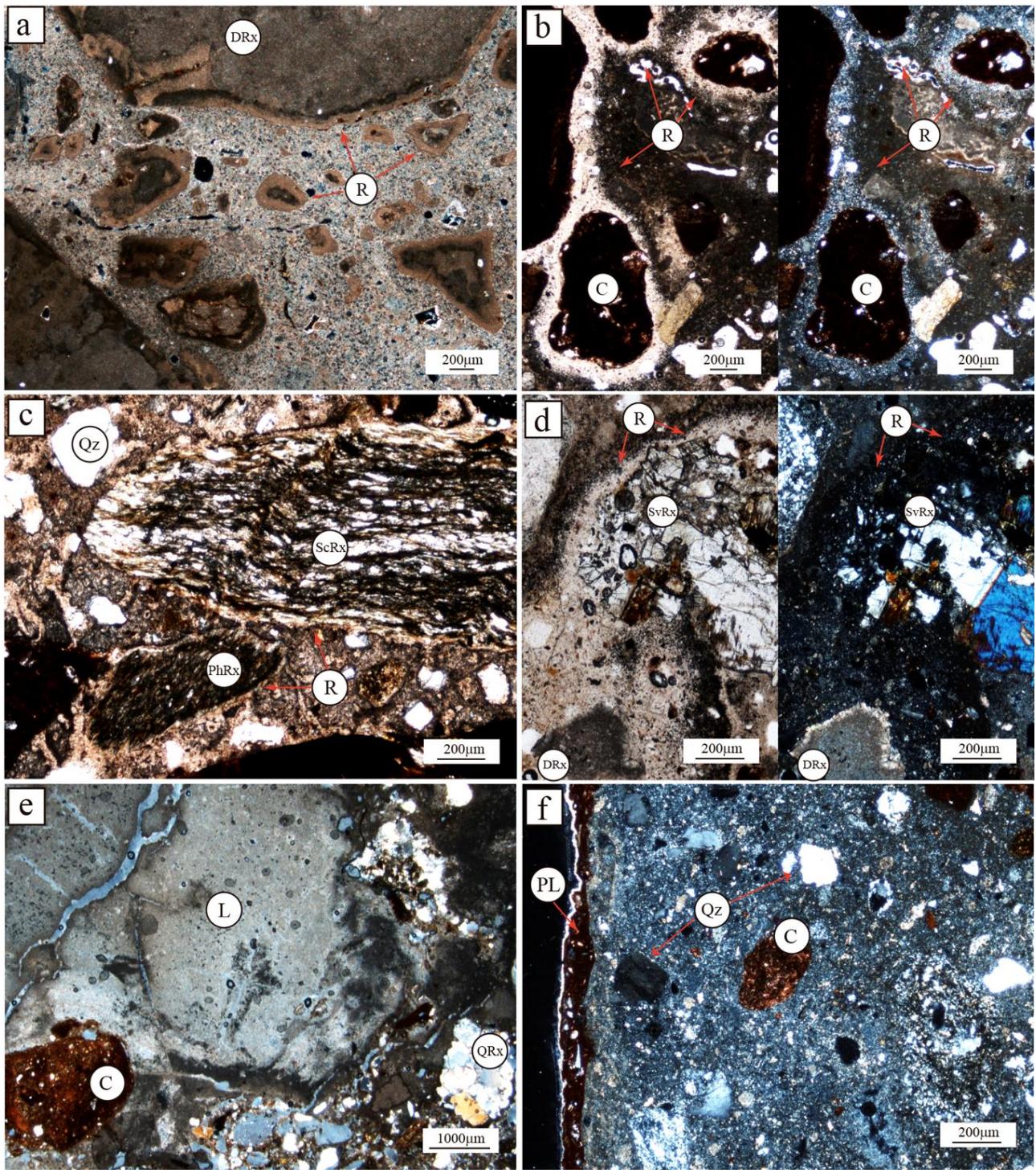

Figure 4. Photomicrographs showing the most representative microtextures of the lime mortars from Amaiur Castle cistern. (a), (b)-left, (c) and (d)-left: plane polarized light mode (PPL). (b)-right, (d)-right, $(\mathbf{e}, \mathbf{f})$ : crossed-polarized light mode (XPL). C: ceramic; DRx: dolostone; L: lime lump; PhRx: phyllite; PL: pigmented layer; QRx: quartzite; Qz: quartz; R: reaction zone; ScRx: Schist; SvRx: subvolcanic rock.

The nature of the aggregates from the cistern tank mortars is the same in both structural mortars (Samples CA-AL-7, CA-AL-8, and CA-AL-9) and plaster (Samples CA-AL-1). Mortars are mainly composed of subangular to rounded ceramic fragments (s.l.), and the siliceous aggregates observed macroscopically have been identified as well-rounded quartz grains and phyllite, schist, quartzite, sandstone, and subvolcanic rocks (Figure $4 \mathrm{~b}-\mathrm{e}$ ). Dolostone fragments were also observed in minor amounts, and also some charcoal fragments were dispersed in the binder matrix. Heterometric lime lumps up to $4 \mathrm{~mm}$ were also observed (Figure 4e).

The grain size of aggregates decreases and aggregate sorting increases from the inner layer of the structural mortar (Sample CA-AL-7) to the outer part (CA-AL-8 and CA-AL-9). Sample CA-AL-7 shows very poorly sorted aggregates from $0.7 \mathrm{~mm}$ to $2 \mathrm{~cm}$ in size. The outer part of Sample CA-AL-8 (CA-AL-8a) is very similar to Sample CA-AL-9, with smaller and more sorted aggregates than the 
inner part of Sample CA-AL-8 (CA-AL-8b). Both Subsample CA-AL-8b and Sample CA-AL-9 show moderately sorted aggregates ranging from $0.2 \mathrm{~mm}$ up to $3 \mathrm{~mm}$ in grain size, whereas Subsample CA-AL-8a shows better sorted aggregates from 0.1 to $1.3 \mathrm{~mm}$ in size.

Sample CA-AL-1 corresponding to the plaster mortar consists of two different layers (Figure 4f). The inner layer of the plaster is also composed by the well-rounded and sorted ceramic and polygenic rock aggregates, as observed in the structural mortars of the cistern, which are up to $0.3 \mathrm{~mm}$ in size. The outer layer of the plaster is a reddish pigmented layer around $0.15 \mathrm{~mm}$ thick showing a scarce amount of mica-like phyllosilicates and quartz grains.

Binder/aggregate ratios were defined by the comparison of the chart for volume percentage estimation [26]. Samples show a binder/aggregate ratio between 1:2 and 1:1, except for Sample CA-AL-7, which shows a binder/aggregate ratio of 1:1 and the inner layer of plaster, which shows a binder/aggregates ratio of 2:1.

To determine the composition of the mortar binders, Sample CA-AL-2 from the vault lunette, Sample CA-AL-9 from the structural mortars of the tank, and both inner and pigmented layers of plaster (Sample CA-AL-1) were selected for X-ray diffraction (XRD) analysis.

A binder fraction $<2 \mu \mathrm{m}$ of Samples CA-AL-2 and CA-AL-9 was extracted in order to avoid the interference of the aggregate composition following the procedures described by Ortega et al. [27] and Ponce-Anton et al. [28]. The small amount of Sample CA-AL-1 from the plaster made it impossible to extract the binder fraction $<2 \mu \mathrm{m}$, and thus the bulk fraction of both inner and pigmented layers was analysed. For the analysis of the inner layer, the aggregates observable with the naked eye were removed.

The XRD results are shown in Figure 5. All samples are mainly composed of magnesium calcite $\left[(\mathrm{Ca}, \mathrm{Mg}) \mathrm{CO}_{3}\right]$, and in minor amounts, hydrotalcite $\left[\mathrm{Mg}_{6} \mathrm{Al}_{2}\left(\mathrm{CO}_{3}\right)(\mathrm{OH})_{16} \cdot 4\left(\mathrm{H}_{2} \mathrm{O}\right)\right]$ was also detected in all samples, except in the pigmented layer where only traces were detected. Quartz $\left[\mathrm{SiO}_{2}\right]$ and illite-like phyllosilicates were detected in samples from the cistern tank in both structural and plaster mortars. Reflection peaks at $7.03 \AA$ and $3.51 \AA$ allowed to detect small amounts of the amesite mineral phase $\left[\mathrm{Mg}_{2} \mathrm{Al}_{2} \mathrm{SiO}_{5}(\mathrm{OH})_{4}\right]$ in Sample CA-AL-9 and in the inner layer of the plaster. Hematite $\left[\mathrm{Fe}_{2} \mathrm{O}_{3}\right]$ was also identified in the pigmented outermost layer of the plaster.

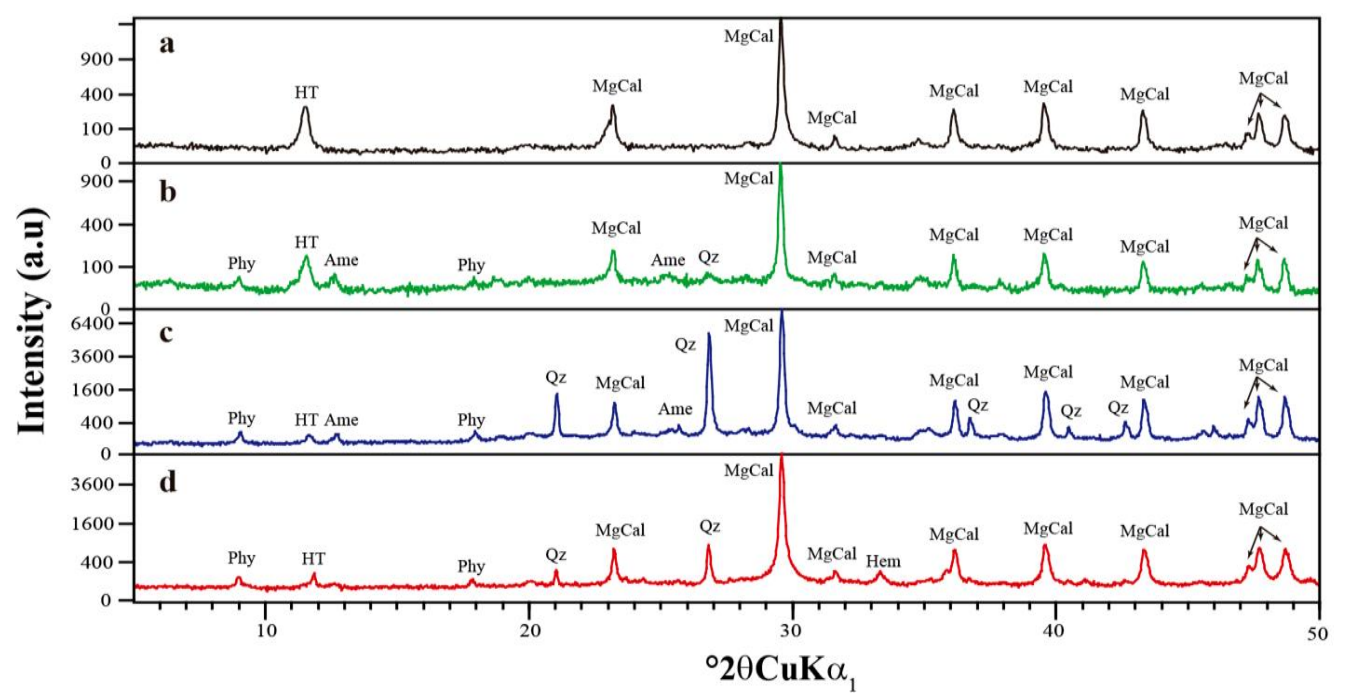

Figure 5. X-ray diffraction patterns of the lime mortars from Amaiur Castle cistern. (a) Binder fraction $<2 \mu \mathrm{m}$ from the lunette. (b) Binder fraction $<2 \mu \mathrm{m}$ from the structural mortar of the tank. (c) Bulk fraction from the inner layer of the plaster mortar. (d) Bulk fraction from the pigmented layer of the plaster mortar. Ame: amesite, Hem: hematite, HT: hydrotalcite; Mg-cal: magnesium calcite, Phy: phyllosilicates s.l., Qz: quartz. 
Both hydrotalcite and amesite have been the Mg-hydrated phases detected by XRD. Hydrotalcite is a layered double hydroxide phase (LDHs) [29], whereas amesite is a magnesium aluminosilicate hydrate phase (M-A-S-H).

To confirm the presence of the Mg-hydrated phases detected by XRD, the binder fraction $<2 \mu \mathrm{m}$ of Samples CA-AL-2 (vault mortar) and CA-AL-9 (tank mortar) were analysed by thermogravimetric analysis (TGA). The TGA results are shown in Figure 6.

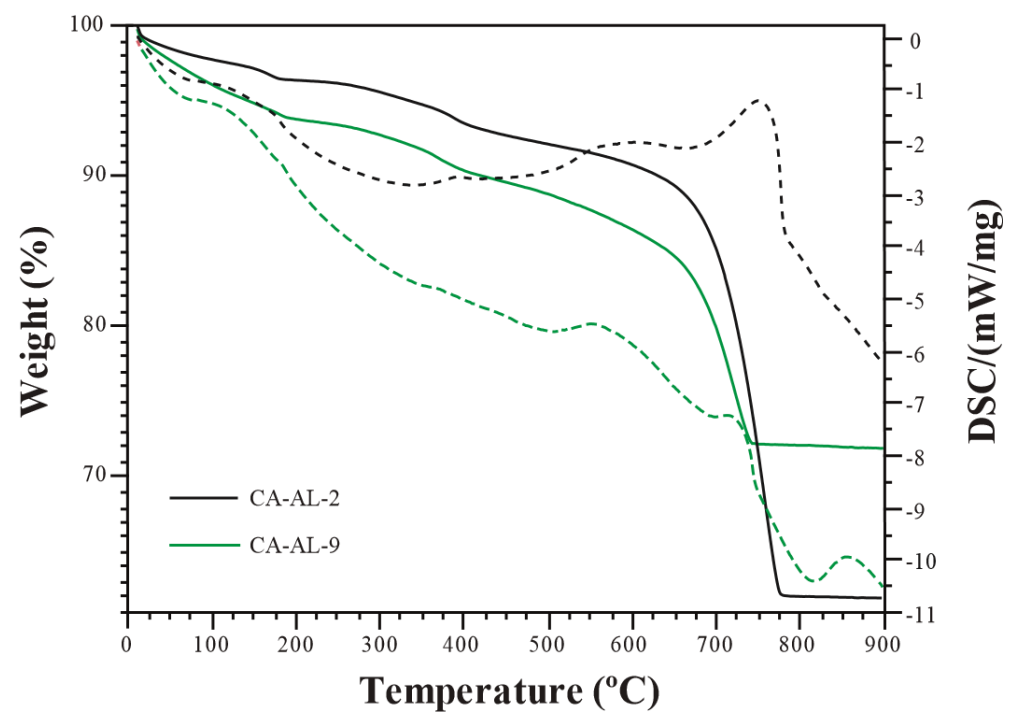

Figure 6. Thermogravimetric analyses of the binder fraction $<2 \mu \mathrm{m}$ from the vault mortar (Sample CA-AL-2 in black) and tank mortar (Sample CA-AL-9 in green).

Sample CA-AL-2 shows a total weight loss of 38.14\%, whereas Sample CA-AL-9 shows a total weight loss of $28.17 \%$. Since the total weight loss of pure calcium carbonate is $44 \%$, these lower weight losses indicate the presence of other mineral phases in the binder as indicated by the XRD results (Figure 5).

The TGA curves show four main weight loss regions. The first weight loss $\left(<120^{\circ} \mathrm{C}\right)$ and the second weight loss $\left(120\right.$ to $\left.200^{\circ} \mathrm{C}\right)$ are attributed to the adsorption water and poorly bonded interlayer water, respectively. The third weight loss $\left(200\right.$ to $\left.600^{\circ} \mathrm{C}\right)$ is attributed to dehydration caused by the loss of hydroxyl groups $\left(\mathrm{OH}^{-}\right)$. The last fourth weight loss $\left(600\right.$ to $\left.800^{\circ} \mathrm{C}\right)$ is related to the decomposition of the carbonates [30-32]. No weight loss is observed over $800^{\circ} \mathrm{C}$. Considering the DSC curve, between 200 and $600^{\circ} \mathrm{C}$, two endothermic peaks are observed in both Sample CA-AL-2 and Sample CA-AL-9. These two endothermic peaks correspond to the hydrotalcite (LDHs), which decomposes in two steps in this range of temperatures [33,34]. Nevertheless, the second endothermic peak between 450 and $600{ }^{\circ} \mathrm{C}$ can also be related to the decomposition of the amesite (M-A-S-H) and illite-like phyllosilicates [35-38] present in Sample CA-AL-9, and therefore, they appear to overlap. Between 800 and $900{ }^{\circ} \mathrm{C}$, an endothermic peak is only detected in Sample CA-AL-9, confirming the presence of amesite and illite in the tank mortar sample, since the breakdown of both phases takes place in this temperature range [35-37].

$X$-ray fluorescence was performed to determine the chemical composition of the binder fraction $<2 \mu \mathrm{m}$ of Samples CA-AL-2 and CA-AL-9. Chemical results of both vault and tank mortars (Samples CA-AL-2 and CA-AL-9, respectively) were used to calculate the Hydraulicity Index (HI) and Cementation Index (CI) in order to assess and compare the hydraulicity degree of binders from the vault and tank (Table 2). Hydraulicity is classified as weak ( $\mathrm{HI}=0.1-0.2, \mathrm{CI}=0.3-0.5)$, moderate $(\mathrm{HI}=0.2-0.4, \mathrm{CI}=0.5-0.7)$, and eminent $(\mathrm{HI}<0.4, \mathrm{CI}=0.7-1.1)[24,25]$. According to the $\mathrm{HI}$ and $\mathrm{CI}$ values, the mortar binder from the cistern tank is eminently hydraulic, whereas the mortar binder from the vault is weakly hydraulic. 
Table 2. Semiquantitative results of the major elements of the binder fraction $<2 \mu \mathrm{m}$ in powder samples from the lunette of the barrel vault and tank samples determined by $\mathrm{X}$-ray fluorescence, the hydraulicity index $(\mathrm{HI})$, and the cementation index $(\mathrm{CI})$. Chemical results are expressed as oxides in $\mathrm{wt} \%$. Iron content is expressed as total $\mathrm{Fe}_{2} \mathrm{O}_{3}$ t. LOI: loss on ignition (\%).

\begin{tabular}{ccccccccccccc}
\hline Sample & Structure & $\mathbf{M g O}$ & $\mathbf{A l}_{\mathbf{2}} \mathbf{O}_{\mathbf{3}}$ & $\mathbf{S i O}_{\mathbf{2}}$ & $\mathbf{K}_{\mathbf{2}} \mathbf{O}$ & $\mathbf{C a O}$ & $\mathbf{T i O}_{\mathbf{2}}$ & $\mathbf{M n O}$ & $\mathbf{F e}_{\mathbf{2}} \mathbf{O}_{\mathbf{3}} \mathbf{t}$ & $\mathbf{L O I}$ & $\mathbf{H I}$ & $\mathbf{C I}$ \\
\hline CA-AL-2 & Lunette & 6.16 & 2.43 & 5.55 & 0.23 & 44.73 & 0.20 & 0.05 & 2.40 & 38.14 & 0.20 & 0.37 \\
CA-AL-9 & Tank & 6.70 & 8.15 & 21.12 & 1.08 & 29.20 & 0.35 & 0.15 & 4.88 & 28.17 & 0.95 & 1.85 \\
\hline
\end{tabular}

\subsection{Study of the Pigmented Layer of Plaster}

Scanning electron microscopy (SEM) was performed on Sample CA-AL-1 for better characterization of the plaster. SEM observations show that the pigmented layer of plaster is less porous than the inner layer and that the contact surface between both layers is rough (Figure 7).

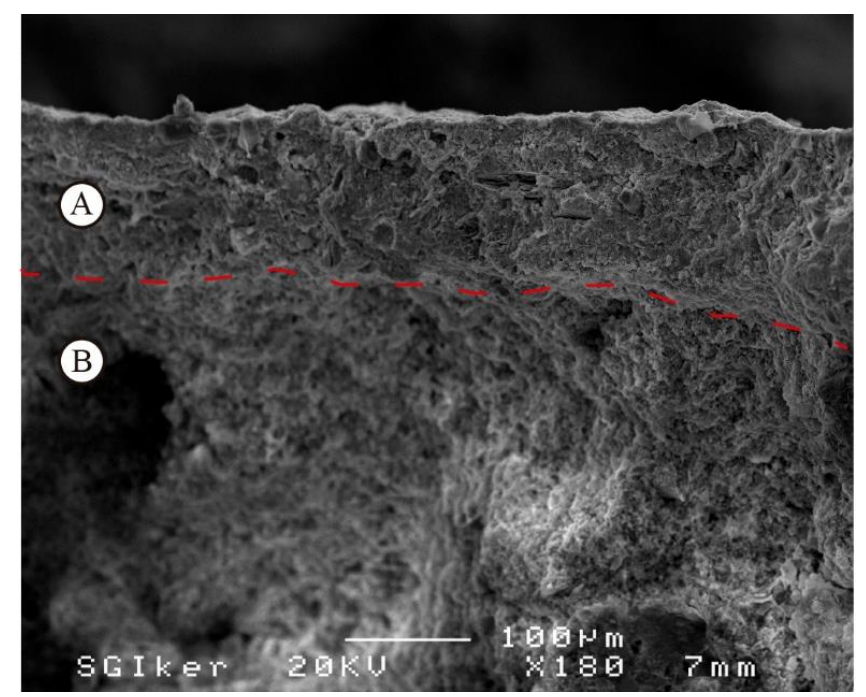

Figure 7. SEM image of the cistern plaster. A: pigmented layer; B: inner layer. Rough contact surface in red.

The outermost pigmented layer of the plaster was also analysed by Raman spectroscopy and Fourier transform infrared spectroscopy (FTIR) in order to determine whether any other type of additive was used in the manufacture. Raman spectroscopy confirmed that the pigmented layer of plaster is mainly composed of a mixture of calcite and hematite (Figure 8a).

Raman spectra show intense bands at $282 \mathrm{~cm}^{-1}, 712 \mathrm{~cm}^{-1}$, and $1087 \mathrm{~cm}^{-1}$ attributed to calcite and less intense bands at $226 \mathrm{~cm}^{-1}, 294 \mathrm{~cm}^{-1}$, and $410 \mathrm{~cm}^{-1}$ attributed to hematite [39,40]. Broad bands at 355 and $464 \mathrm{~cm}^{-1}$ related to quartz are also observed. The broad band identified in the region of $1150-1450 \mathrm{~cm}^{-1}$ is attributed to an organic compound, but due to the low quality of the spectrum, it was difficult to identify (Figure 8b).

Infrared spectroscopy (FTIR) analysis was performed in order to identify the organic compound detected by Raman spectroscopy. FTIR spectra show bands at $2864 \mathrm{~cm}^{-1}, 2514 \mathrm{~cm}^{-1}, 1794 \mathrm{~cm}^{-1}$, $1428 \mathrm{~cm}^{-1}, 871 \mathrm{~cm}^{-1}$, and $711 \mathrm{~cm}^{-1}$ attributed to calcite and bands at $1027 \mathrm{~cm}^{-1}, 642 \mathrm{~cm}^{-1}$ and $528 \mathrm{~cm}^{-1}$ attributed to the hematite (red earth pigment) (Figure 9a) [41-43]. Nevertheless, the strong absorption of the inorganic phases hides the signal of the organic compound, hindering its identification. To improve the FTIR signal of the organic component, an extraction was conducted using $200 \mu \mathrm{L}$ of dichloromethane. The resulted supernatant was evaporated on a potassium bromide disk to be then analysed. The intense bands detected at $2955 \mathrm{~cm}^{-1}, 2916 \mathrm{~cm}^{-1}, 2848 \mathrm{~cm}^{-1}, 1736 \mathrm{~cm}^{-1}$, and $1472 \mathrm{~cm}^{-1}$ were attributed to beeswax organic compound (Figure 9b) [43]. 

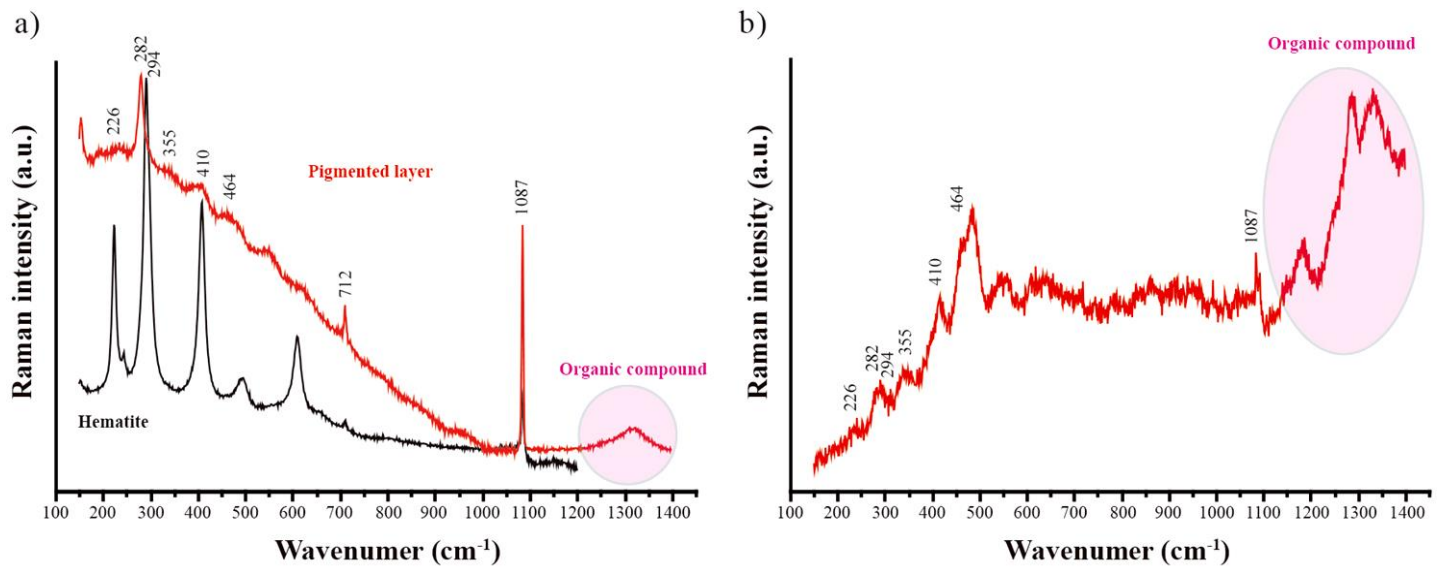

Figure 8. Raman spectroscopy of the bulk fraction of the pigmented layer of the cistern plaster. (a) Raman spectra showing the highest intensities bands of calcite, hematite, and quartz. (b) Raman spectra showing an organic compound in the region of $1150-1450 \mathrm{~cm}^{-1}$. Calcite bands at $282 \mathrm{~cm}^{-1}$, $712 \mathrm{~cm}^{-1}$, and $1087 \mathrm{~cm}^{-1}$; hematite bands at $226 \mathrm{~cm}^{-1}, 294 \mathrm{~cm}^{-1}$, and $410 \mathrm{~cm}^{-1}$; quartz bands at $355 \mathrm{~cm}^{-1}$ and $464 \mathrm{~cm}^{-1}$.

a)

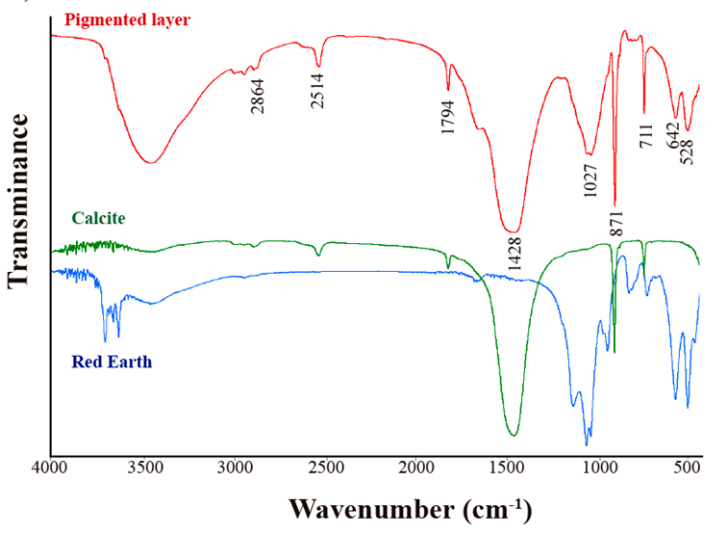

b)

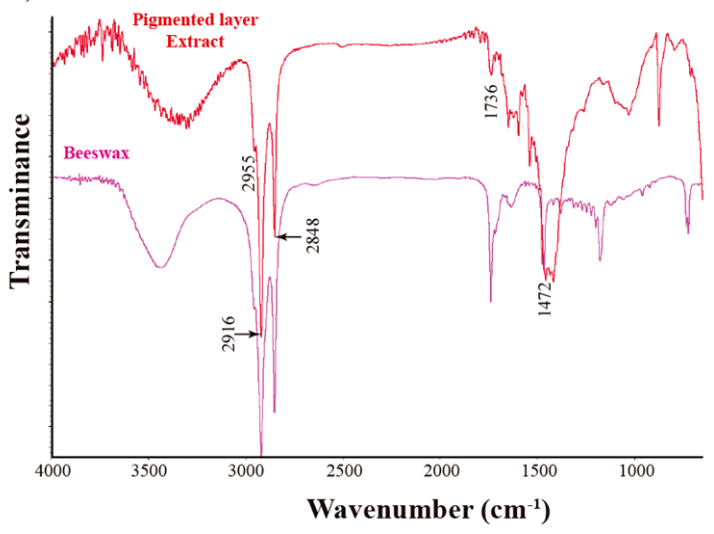

Figure 9. Fourier transform infrared spectroscopy (FTIR) analysis of the pigmented layer of the cistern plaster. (a) FTIR spectra showing the highest intensities bands of calcite and hematite (red earth). (b) FTIR spectra showing the highest intensities bands of the organic compound identified as beeswax. Calcite bands at $2864 \mathrm{~cm}^{-1}, 2514 \mathrm{~cm}^{-1}, 1794 \mathrm{~cm}^{-1}, 1428 \mathrm{~cm}^{-1}, 871 \mathrm{~cm}^{-1}$, and $711 \mathrm{~cm}^{-1}$; hematite (red earth) bands at $1027 \mathrm{~cm}^{-1}, 642 \mathrm{~cm}^{-1}$, and $528 \mathrm{~cm}^{-1}$. Beeswax bands at $2955 \mathrm{~cm}^{-1}, 2916 \mathrm{~cm}^{-1}, 2848 \mathrm{~cm}^{-1}$, $1736 \mathrm{~cm}^{-1}$, and $1472 \mathrm{~cm}^{-1}$.

\section{Discussion}

Petrological study suggests a careful process in both the mortar manufacture and mortar application technique for the cistern construction according to the specific characteristics needed for this structure. The impermeability of the cistern tank is an essential requirement for appropriate water storage. Mortar impermeability is strictly related to mortar hydraulicity, which is favoured by the use of silico-aluminous aggregates working as reactive materials in the mixture [8,10-13]. The use of silico-aluminous rocks and ceramic fragments as aggregates in the tank mortar manufacture, instead of the carbonated aggregates used for the vault mortars, indicates a deliberate selection of aggregates in order to confer hydraulicity to the mortar to obtain waterproof mortars. Furthermore, the use of silico-aluminous aggregates adds greater cohesion and mechanical strength to the mortar $[44,45]$.

The raw materials that were used as aggregates to manufacture both the lime mortars from the vault and cistern tank correspond to the surrounding geological materials. Not only the selection of aggregates was important but also the aggregate sorting. The grain size of aggregates in the 
tank mortars becomes smaller and better sorted from the first layer of the structural mortar toward the outermost pigmented layer of the plaster. Besides, aggregate size also contributes to material reactivity, since the smaller the size, the higher the specific surface area and thus the higher the reaction rate [8,46-48]. Furthermore, mortar porosity is lower in mortars with better-sorted aggregates since they produce a better-packed system [49-52].

The mineralogical analyses allowed identifying additives in the pigmented layer. The XRD, Raman, and FTIR analyses indicate that hematite was used as an inorganic additive, which led to the reddish colour of the pigmented layer (Figures 5, 8 and 9). Hematite would not be related to ceramic fragments, since they were not observed either in the petrographic study or by XRD (Figures $4 \mathrm{f}$ and $5 \mathrm{~d}$ ). Therefore, the hematite may have been deliberately added. FTIR analyses allowed identifying the beeswax as the organic additive in the pigmented layer (Figure 9). Beeswax was the most common natural wax used as an organic additive to provide impermeability and sealing property to the materials [53]. Since organic compounds are more susceptible to degradation than inorganic compounds, knowledge of the composition of ancient additives is essential for appropriate interventions on archaeological structures [53,54].

Therefore, to ensure the impermeability of the cistern tank, a multilayer application of different mortars was performed using silico-aluminous aggregates and decreasing their grain size from the first layer of the structural mortar toward the inner layer and applying a final plaster with a beeswax-bearing pigmented layer (Figure 10).

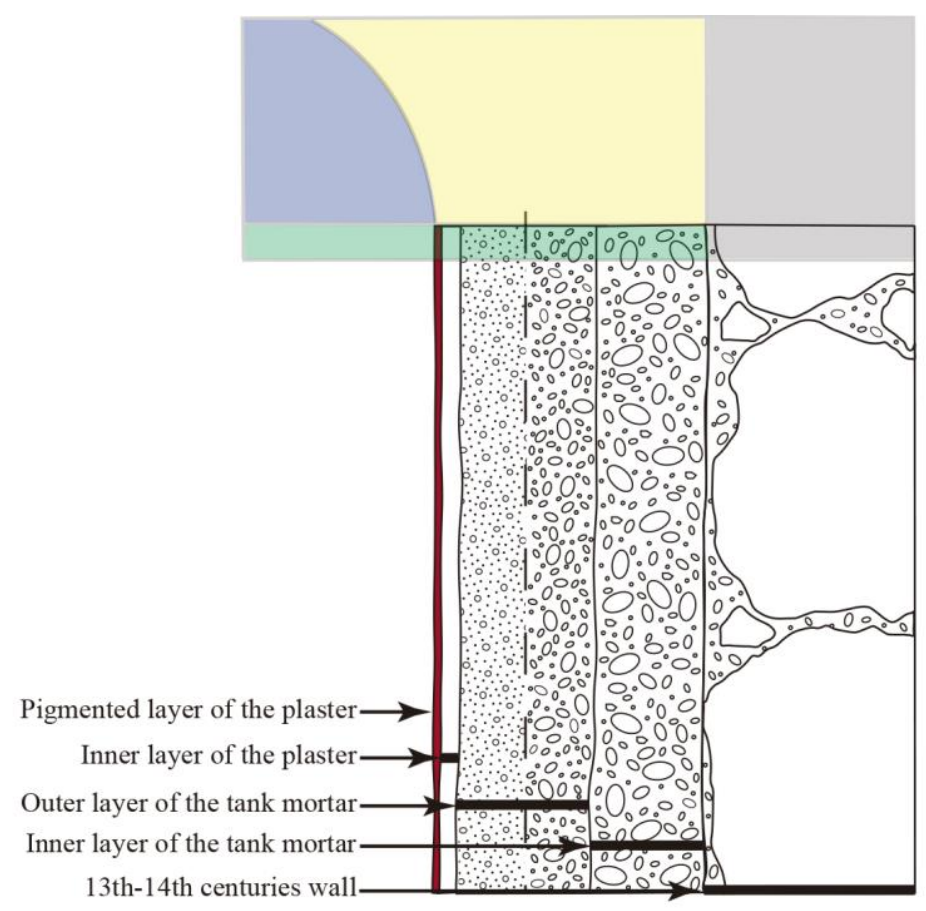

Figure 10. Schematic image of the multilayer application technique for mortars in Amaiur Castle cistern. The cistern tank is shown in green, the vault lunette is shown in blue, the barrel vault is shown in yellow, and the 14th-15th centuries wall is shown in black.

Furthermore, the reaction zones observed in dolomitic aggregates resulted from the dedolomitization of dolomitic aggregates, and the presence of hydrotalcite in the binder has been related to the use of the traditional hot-mixing method in mortar manufacture [23]. In the manufacture of cistern tank mortars, the use of this traditional hot-mixing method would also be expected since reaction zones were not only observed at the edge of the dolomitic aggregates, but they also stand out in the ceramic fragments and some silico-aluminous aggregates (Figure $4 a-d$ ). 
Quartz and phyllosilicates are attributed to the ceramic fragments and silico-aluminous rocks used as aggregates, whereas magnesium calcite, hydrotalcite, and amesite are mineral phases formed during mortar manufacture (Figure 5). Magnesium calcite is formed in the setting of mortar as a result of the lime cycle $[24,55]$, and hydrotalcite is a carbonated mineral formed during the slaking process in the presence of available magnesium content [28].

Hydrotalcite has been identified in all analysed mortar binders (Figure 5). Magnesium released from the dedolomitization process, leading to the formation of the reaction zone in the edge of dolomitic aggregates, and the aluminium released from the breakdown of phyllosilicates favours the formation of hydrotalcite $[23,56-58]$. Nevertheless, some amount of magnesium and aluminium can also come from the lime used for the mortar manufacture when impure limestones or partially dolomitized limestones have been used as the raw material for lime production [28,59]. Therefore, the presence of hydrotalcite and the absence of dolomitic aggregates in the pigmented layer of plaster (Figures 4 and 5) would indicate the use of impure limestones or partially dolomitized limestones for the production of lime for the cistern construction.

The aluminosilicate phases present in the silico-aluminous aggregates of the tank mortars are highly reactive materials that in the presence of alkalis react with water, forming a wide family of hydration products that induce hydraulic properties to the mortars $[8,15,46]$. Reaction zones observed in the edge of the silico-aluminous aggregates suggest the development of this reaction (Figure $4 \mathrm{~b}-\mathrm{d}$ ). The reaction between aluminosilicate phases and an alkaline solution is known as an alkali-silicate reaction (ASSR), which is a specific type of alkali-silica reaction (ASR) [60-62].

Amesite has been the only aluminosilicate hydrated phase detected in the tank mortars. This mineral phase has also been described in some mortars with pozzolanic aggregates $[48,63]$. Amesite is a magnesium aluminosilicate hydrate (M-A-S-H) phase, and although it is chemically related to chlorites, it displays a similar structure to serpentine with alternating tetrahedral and trioctahedral layers [37]. The amesite has only been detected in samples containing silico-aluminous aggregates, indicating that it would have formed as a result of the reaction between the aluminosilicate phases and the putty alkalis.

Magnesium silicate hydrate (M-S-H) phases have been described during the hydration of $\mathrm{MgO}-$ bearing lime materials and formed by the reaction between magnesium and silicate ions [64-66]. The M-S-H phases show a layered structure and have been related to poorly crystalline phyllosilicates [64, 66-69]. The reaction zone of the dolomitic aggregates of the structural mortars from Amaiur Castle showed the presence of M-S-H phases, which are suggested as a result of an ASSR, although the presence of the M-S-H phases could not be confirmed [23]. According to Mackenzie and Bowden [37], amesite is formed by the substitution of the $\mathrm{Si}^{4+}$ in the tetrahedral layers and the $\mathrm{Mg}^{2+}$ in the octahedral layers by the $\mathrm{Al}^{3+}$. Therefore, the amesite detected in the mortars from the cistern tank could also have been formed as a result of the ASSR, since the kinetic formation of M-A-S-H phases has been described as similar to M-S-H phases, incorporating aluminium into the structure $[63,70]$.

Besides, the phases formed as a result of the reaction between the aluminosilicate phases of the silico-aluminous aggregates and the putty alkalis contribute to decreasing the porosity and therefore favour the waterproofing of the cistern tank [45,71-73].

The study of both structural and plaster mortars from Amaiur Castle cistern show patterns/rules in the mortar manufacture according to the specific construction requirements, distinguishing two kinds of mortars with aggregates of different nature. Mortars from the cistern tank acquired hydraulicity by the addition of silico-aluminous rocks and ceramic fragments as aggregates.

\section{Conclusions}

The study of the mortars from the Amaiur Castle cistern has allowed assessing the knowledge of the mortar manufacturing process and the mortar application techniques to ensure the structure waterproofing necessary for the correct storage of water. 
The cistern shows three types of lime mortars with different compositional characteristics related to the specific function within the structure: structural mortars from the barrel vault, structural mortars from the tank, and plaster.

The nature of the aggregates used in the manufacture of cistern mortars was different, according to specific construction requirements. Carbonated aggregates were used in the vault mortar and silicious and silico-aluminous aggregates in the tank mortars and plaster, suggesting the specific selection of raw materials.

The raw materials of the surrounding geological materials were used for the manufacture of the lime mortars of the cistern of the Amaiur Castle.

To confer hydraulicity to the mortars of the cistern tank and achieve the waterproofing of the structure, ceramic fragments and silico-aluminous rocks were used as aggregates in the manufacture.

Besides, the reaction zones on the edge of silico-aluminous rocks and ceramic aggregates resulted from an alkali silicate reaction (ASSR) that favoured the formation of amesite, the magnesium aluminosilicate hydrated (M-A-S-H) phase detected in the binder of the tank mortars.

A multilayering application technique was performed in the construction of the cistern tank. Two/three layers have been differentiated in the structural mortar from the tank, with a decrease in grain size and an improvement in sorting of aggregates from the inner part to the outer part. The plaster is formed by two layers: an inner layer and an outer pigmented layer.

The pigmented layer of plaster is composed by two types of additives. Hematite was identified as an inorganic additive giving rise to the reddish colour of the layer. Additionally, beeswax was identified as an organic additive used to confer impermeability to the pigmented layer.

The presence of hydrotalcite and the absence of dolomitic aggregates in the pigmented layer point to the use of impure limestones or partially dolomitized limestones as the raw material for the production of lime at Amaiur Castle.

Author Contributions: Conceptualization, G.P.-A., M.C.Z. and L.A.O.; Data Curation, G.P.-A. and M.C.Z.; Writing-Original Draft Preparation, G.P.-A.; Writing-Review and Editing, G.P.-A., M.C.Z.; Funding Acquisition, L.A.O. and J.A.M. All authors have read and agreed to the published version of the manuscript.

Funding: This research was funded by the IT1193-13 project of the Basque Government.

Acknowledgments: G.P.-A. acknowledges the PhD research grant of the Basque Government 2015-1-02-35. The authors would like to thank Peter Smith for reviewing the use of English in the manuscript.

Conflicts of Interest: The authors declare no conflict of interest.

\section{References}

1. Cadogan, G. Water management in Minoan Crete, Greece: The two cisterns of one Middle Bronze Age settlement. Water Sci. Technol. Water Supply 2007, 7, 103-112. [CrossRef]

2. Angelakis, A.N.; Spyridakis, D.S. Water supply and wastewater management aspects in Ancient Greece. Water Sci. Technol. Water Supply 2010, 10, 618-628. [CrossRef]

3. Angelakis, A.N.; Mays, L.W.; Koutsoyiannis, D.; Mamassis, N. Evolution of Water Supply through the Millennia; IWA Publishing: London, UK, 2012.

4. Carrion, A.; Formnes, A. Underground medieval water distribution network in a Spanish town. Tunn. Undergr. Space Technol. 2016, 51, 90-97. [CrossRef]

5. Mays, L.; Antoniou, G.P.; Angelakis, A.N. History of Water Cisterns: Legacies and Lessons. Water 2013, 5, 1916-1940. [CrossRef]

6. Van Hees, R.P.J.; Binda, L.; Papayianni, I.; Toumbakari, E. Characterisation and damage analysis of old mortars. Mater. Struct. 2004, 37, 644-648. [CrossRef]

7. Stefanidou, M.; Pachta, V.; Konopissi, S.; Karkadelidou, F.; Papayianni, I. Analysis and characterization of hydraulic mortars from ancient cisterns and baths in Greece. Mater. Struct. 2014, 47, 571-580. [CrossRef]

8. Rizzo, G.; Ercoli, L.; Megna, B.; Parlapiano, M. Characterization of mortars from ancient and traditional water supply systems in Sicily. J. Therm. Anal. Calorim. 2008, 92, 323-330. [CrossRef] 
9. Henry, A.; Stewart, J. Practical Building Conservation: Mortars, Renders E Plasters; Practical Building Conservation Series; English Heritage: Surrey, UK, 2011.

10. Baronio, G.; Binda, L. Study of the pozzolanicity of some bricks and clays. Constr. Build. Mater. 1997, 11, 41-46. [CrossRef]

11. Baronio, G.; Binda, L.; Lombardini, N. The role of brick pebbles and dust in conglomerates based on hydrated lime and crushed bricks. Constr. Build. Mater. 1997, 11, 33-40. [CrossRef]

12. Stefanidou, M.; Papayianni, I. The role of aggregates on the structure and properties of lime mortars. Cem. Concr. Compos. 2005, 27, 914-919. [CrossRef]

13. Arizzi, A.; Cultrone, G. Aerial lime-based mortars blended with a pozzolanic additive and different admixtures: A mineralogical, textural and physical-mechanical study. Constr. Build. Mater. 2012, 31, 135-143. [CrossRef]

14. Miriello, D.; Bloise, A.; Crisci, G.M.; De Luca, R.; De Nigris, B.; Martellone, A.; Osannac, M.; Paced, R.; Peccia, A.; Ruggieri, N. New compositional data on ancient mortars and plasters from Pompeii (Campania-Southern Italy): Archaeometric results and considerations about their time evolution. Mater. Charact. 2018, 146, 189-203. [CrossRef]

15. Walker, R.; Pavía, S. Physical properties and reactivity of pozzolans, and their influence on the properties of lime-pozzolan pastes. Mater. Struct. 2011, 44, 1139-1150. [CrossRef]

16. Bonazza, A.; Ciantelli, C.; Sardella, A.; Pecchioni, E.; Favoni, O.; Natali, I.; Sabbioni, C. Characterization of hydraulic mortars from archaeological complexes in Petra. Period. Mineral. 2014, 82, 459.

17. Rampazzi, L.; Colombini, M.P.; Conti, C.; Corti, C.; Lluveras-Tenorio, A.; Sansonetti, A.; Zanaboni, M. Technology of medieval mortars: An investigation into the use of organic additives. Archaeometry 2016, 58, 115-130. [CrossRef]

18. Galán Pérez, E.; García de Domingo, A.; Cabra Gil, A.; Ganzález Lastra, J.; Matinez Torres, L.M.; Pesquera Pérez, A. Memoria Hoja 66-III (Maya de Baztán). In Mapa Geológico de Navarra. E. 1:25000; Diputación Foral de Navarra: Navarra, Spain, 2002.

19. Juch, D.; Krausse, H.F.; Müller, D.; Requadt, H.; Schafer, D.; Sole, J.; Villalobos, L. Memoria Hoja 66 (Maya del Baztan). In Mapa Geológico de España, E. 1:50.000, 1st ed.; Segunda Serie; MAGNA: Magna Drive Aurora, ON, Canada, 1974.

20. AGN. Royal and General Archive of Navarre. In Rena Papers; 15/3, 52, Box 33055: 1516; Government of Navarre: Pamplona, Spain, 1995.

21. Sagredo, I. El castillo de Amaiur a Través de la Historia de Navarra; Editorial Pamiela Argitaletxea: Pamplona, Spain, 2009.

22. Sagredo, I. Navarra. In Castillos que Defendieron el Reino (Tomo I) de Laguardia a Foix, y del Moncayo al Goierri; Editorial Pamiela Argitaletxea: Pamplona, Spain, 2006.

23. Ponce-Antón, G.; Zuluaga, M.C.; Ortega, L.A.; Mauleon, J.A. Multi-analytical approach for chemical-mineralogical characterization of reaction rims in the lime mortars from Amaiur Castle (Navarre, Spain). Microchem. J. 2020, 152, 104303. [CrossRef]

24. Boynton, R.S. Chemistry and Technology of Lime and Limestone; John Wiley \& Sons, Inc.: New York, NY, USA, 1980.

25. Vicat, L.J. Mortars and Cements; Donhead Publishing: Shaftesbury, UK, 1997.

26. Folk, R.L. A comparison chart for visual percentage estimation. J. Sediment. Res. 1951, 21, 32-33.

27. Ortega, L.A.; Zuluaga, M.C.; Alonso-Olazabal, A.; Murelaga, X.; Insausti, M.; Ibañez-Etxeberria, A. Historic lime-mortar 14C dating of Santa María la Real (Zarautz, northern Spain): Extraction of suitable grain size for reliable $14 \mathrm{C}$ dating. Radiocarbon 2012, 54, 23-36. [CrossRef]

28. Ponce-Antón, G.; Ortega, L.A.; Zuluaga, M.C.; Alonso-Olazabal, A.; Solaun, J.L. Hydrotalcite and Hydrocalumite in Mortar Binders from the Medieval Castle of Portilla (Álava, North Spain): Accurate Mineralogical Control to Achieve More Reliable Chronological Ages. Minerals 2018, 8, 326. [CrossRef]

29. Mills, S.J.; Christy, A.G.; Génin, J.-M.R.; Kameda, T.; Colombo, F. Nomenclature of the hydrotalcite supergroup: Natural layered double hydroxides. Mineral. Mag. 2012, 76, 1289-1336. [CrossRef]

30. Bakolas, A.; Biscontin, G.; Moropoulou, A.; Zendri, E. Characterization of structural byzantine mortars by thermogravimetric analysis. Thermochim. Acta 1998, 321, 151-160. [CrossRef]

31. Paama, L.; Pitkänen, I.; Rönkkömäki, H.; Perämäki, P. Thermal and infrared spectroscopic characterization of historical mortars. Thermochim. Acta 1998, 320, 127-133. [CrossRef] 
32. Moropoulou, A.; Bakolas, A.; Anagnostopoulou, S. Composite materials in ancient structures. Cem. Concr. Compos. 2005, 27, 295-300. [CrossRef]

33. Yang, W.; Kim, Y.; Liu, P.K.T.; Sahimi, M.; Tsotsis, T.T. A study by in situ techniques of the thermal evolution of the structure of a Mg-Al- $-\mathrm{CO}_{3}$ layered double hydroxide. Chem. Eng. Sci. 2002, 57, 2945-2953. [CrossRef]

34. León, M.; Díaz, E.; Bennici, S.; Vega, A.; Ordóñez, S.; Auroux, A. Adsorption of $\mathrm{CO}_{2}$ on Hydrotalcite-Derived Mixed Oxides: Sorption Mechanisms and Consequences for Adsorption Irreversibility. Ind. Eng. Chem. Res. 2010, 49, 3663-3671. [CrossRef]

35. Brindley, G.W.; Oughton, B.M.; Youell, R.F. The crystal structure of amesite and its thermal decomposition. Acta Crystallogr. 1951, 4, 552-557. [CrossRef]

36. Grim, R.E. Applied Clay Mineralogy; Mc Graw-Hill: New York, NY, USA, 1962.

37. MacKenzie, K.J.D.; Bowden, M.E. Thermal and Mössbauer studies of iron-containing hydrous silicates. IV. Amesite. Thermochim. Acta 1983, 64, 83-106. [CrossRef]

38. Drits, V.A.; McCarty, D.K. The nature of structure-bonded $\mathrm{H}_{2} \mathrm{O}$ in illite and leucophyllite from dehydration and dehydroxylation experiments. Clays Clay Miner. 2007, 55, 45-58. [CrossRef]

39. Duran, A.; Jimenez De Haro, M.C.; Perez-Rodriguez, J.L.; Franquelo, M.L.; Herrera, L.K.; Justo, A. Determination of pigments and binders in Pompeian wall paintings using synchrotron radiation-high-resolution X-ray powder diffraction and conventional spectroscopy-chromatography. Archaeometry 2010, 52, 286-307. [CrossRef]

40. Franquelo, M.L.; Robador, M.D.; Ranirez-Valle, V.; Duran, A.; Jimenez de Haro, M.C.; Pérez-Rodríguez, J.L. Roman ceramics of hydraulic mortars used to build the Mithraeum house of Mérida (Spain). J. Therm. Anal. Calorim. 2008, 92, 331-335. [CrossRef]

41. Farmer, V.C. The Infrared Spectra of Minerals; Mineralogical Society of Great Britain and Ireland: London, UK, 1974; Volume 4.

42. Smith, B. Infrared Spectra Interpretation: A Systematic Approach; CRC Press: Florida, FL, USA, 1999.

43. Vahur, S.; Teearu, A.; Peets, P.; Joosu, L.; Leito, I. ATR-FT-IR spectral collection of conservation materials in the extended region of $4000-80 \mathrm{~cm}^{-1}$. Anal. Bioanal. Chem. 2016, 408, 3373-3379. [CrossRef] [PubMed]

44. Odler, I. Hydration, Setting and Hardening of Portland Cement. In Lea's Chemistry of Cement and Concrete; Hewlett, P.C., Ed.; Elsevier: London, UK, 2003; pp. 241-289.

45. Papayianni, I.; Stefanidou, M. Strength-porosity relationships in lime-pozzolan mortars. Constr. Build. Mater. 2006, 20, 700-705. [CrossRef]

46. Sabir, B.B.; Wild, S.; Bai, J. Metakaolin and calcined clays as pozzolans for concrete: A review. Cem. Concr. Compos. 2001, 23, 441-454. [CrossRef]

47. Cunha, A.L.C.; Gonçalves, J.P.; Dweck, J. Evaluating the pozzolanic activity of spent catalyst partially substituting type II Portland cement. In Key Engineering Materials; Trans Tech Publications Ltd.: Stafa-Zurich, Switzerland, 2014; Volume 634, pp. 131-138.

48. Arizzi, A.; Cultrone, G. Comparing the pozzolanic activity of aerial lime mortars made with metakaolin and fluid catalytic cracking catalytic residue: A petrographic and physical-mechanical study. Constr. Build. Mater. 2018, 184, 382-390. [CrossRef]

49. Romagnoli, M.; Rivasi, M.R. Optimal size distribution to obtain the densest packing: A different approach. J. Eur. Ceram. Soc. 2007, 27, 1883-1887. [CrossRef]

50. Fung, W.W.S.; Kwan, A.K.H.; Wong, H.H.C. Wet packing of crushed rock fine aggregate. Mater. Struct. 2008, 42, 631-643. [CrossRef]

51. Kwan, A.K.H.; Fung, W.W.S. Packing density measurement and modelling of fine aggregate and mortar. Cem. Concr. Compos. 2009, 31, 349-357. [CrossRef]

52. Arizzi, A.; Cultrone, G. The influence of aggregate texture, morphology and grading on the carbonation of non-hydraulic (aerial) lime-based mortars. Q. J. Eng. Geol. Hydrogeol. 2013, 46, 507-520. [CrossRef]

53. Colombini, M.P.; Modugno, F. Organic Mass Spectrometry in Art and Archaeology; John Wiley \& Sons, Ltd.: Hoboken, NJ, USA, 2009.

54. Luxán, M.P.; Dorrego, F.; Laborde, A. Ancient gypsum mortars from St. Engracia (Zaragoza, Spain): Characterization. Identification of additives and treatments. Cem. Concr. Res. 1995, 25, 1755-1765. [CrossRef]

55. Beruto, D.T.; Vecchiattini, R.; Giordani, M. Solid products and rate-limiting step in the thermal half decomposition of natural dolomite in a $\mathrm{CO}_{2}(\mathrm{~g})$ atmosphere. Thermochim. Acta 2003, 405, 183-194. [CrossRef] 
56. Gan, G.-L.; Spry, P.G.; Cody, A.M. Rim Formation on Iowa Highway Concrete Dolomite Aggregate: The Effects of Dedolomitization Reactions. Environ. Eng. Geosci. 1996, 2, 59-72. [CrossRef]

57. Sipos, P. The structure of Al(III) in strongly alkaline aluminate solutions-A review. J. Mol. Liq. 2009, 146, 1-14. [CrossRef]

58. Zajac, M.; Bremseth, S.K.; Whitehead, M.; Ben Haha, M. Effect of $\mathrm{CaMg}\left(\mathrm{CO}_{3}\right)_{2}$ on hydrate assemblages and mechanical properties of hydrated cement pastes at $40^{\circ} \mathrm{C}$ and $60^{\circ} \mathrm{C}$. Cem. Concr. Res. 2014, 65, 21-29. [CrossRef]

59. Schork, J. Dolomitic Lime in the US. J. Archit. Conserv. 2012, 18, 7-25. [CrossRef]

60. Hobbs, D.W. Alkali-Silica Reaction in Concrete; Thomas Telford: London, UK, 1988.

61. Katayama, T. How to identify carbonate rock reactions in concrete. Mater. Charact. 2004, 53, 85-104. [CrossRef]

62. da Fonseca, J.M.M.; de Souza, V.K.B.; da Silva, D.G.C.; da Silva, D.L.; Monteiro, E.C.B. Alkali-Aggregate Reaction: Definition, Influence and Control. Eng. Appl. Sci. 2018, 3, 12.

63. Braz, I.G.; Shinzato, M.C.; Montanheiro, T.J.; de Almeida, T.M.; de Souza Carvalho, F.M. Effect of the addition of aluminum recycling waste on the pozzolanic activity of sugarcane bagasse ash and zeolite. Waste Biomass Valorization 2019, 10, 3493-3513. [CrossRef]

64. Brew, D.R.M.; Glasser, F.P. Synthesis and characterisation of magnesium silicate hydrate gels. Cem. Concr. Res. 2005, 35, 85-98. [CrossRef]

65. Zhang, T.; Vandeperre, L.J.; Cheeseman, C.R. Formation of magnesium silicate hydrate (MSH) cement pastes using sodium hexametaphosphate. Cem. Concr. Res. 2014, 65, 8-14. [CrossRef]

66. Bernard, E.; Lothenbach, B.; Cau-Dit-Coumes, C.; Chlique, C.; Dauzères, A.; Pochard, I. Magnesium and calcium silicate hydrates, Part I: Investigation of the possible magnesium incorporation in calcium silicate hydrate (C-S-H) and of the calcium in magnesium silicate hydrate (M-S-H). Appl. Geochem. 2018, 89, $229-242$. [CrossRef]

67. Roosz, C.; Grangeon, S.; Blanc, P.; Montouillout, V.; Lothenbach, B.; Henocq, P.; Giffaut, E.; Vieillard, P.; Gaboreau, S. Crystal structure of magnesium silicate hydrates (M-S-H): The relation with 2:1 Mg-Si phyllosilicates. Cem. Concr. Res. 2015, 73, 228-237. [CrossRef]

68. Walling, S.A.; Kinoshita, H.; Bernal, S.A.; Collier, N.C.; Provis, J.L. Structure and properties of binder gels formed in the system $\mathrm{Mg}(\mathrm{OH})_{2}-\mathrm{SiO}_{2}-\mathrm{H}_{2} \mathrm{O}$ for immobilisation of Magnox sludge. Dalton Trans. 2015, 44, 8126-8137. [CrossRef] [PubMed]

69. Nied, D.; Enemark-Rasmussen, K.; L’Hopital, E.; Skibsted, J.; Lothenbach, B. Properties of magnesium silicate hydrates (M-S-H). Cem. Concr. Res. 2016, 79, 323-332. [CrossRef]

70. Bernard, E. Magnesium Silicate Hydrate (MSH) Characterization: Temperature, Calcium, Aluminium and Alkali; University of Burgundy Franche-Comté: Besançon, France, 2017.

71. Schaefer, J.; Hilsdorf, H.K. Ancient and new lime mortars-The correlation between their composition structure and properties. In Conservation of Stone and Other Materials, Prevention and Treatments; Thiel, M.-J., Ed.; (RILEM proceedings. 21,2.); E \& FN Spon: London, UK, 1993; Volume 2, pp. 605-612.

72. Papayianni, I.; Stefanidou, M. The Evolution of Porosity in Lime-Based Mortars. In Proceedings of the 8th Euroseminar on Microscopy Applied to Building Materials, Athens, Greece, 4-7 September 2001; pp. 451-458.

73. Thomson, M.; Lindqvist, J.E.; Elsen, J.; Groot, C.J.W.P. 2.5. Porosity of Mortars; RILEM Publications SARL: Cachan, France, 2007; pp. 77-106.

(C) 2020 by the authors. Licensee MDPI, Basel, Switzerland. This article is an open access article distributed under the terms and conditions of the Creative Commons Attribution (CC BY) license (http://creativecommons.org/licenses/by/4.0/). 